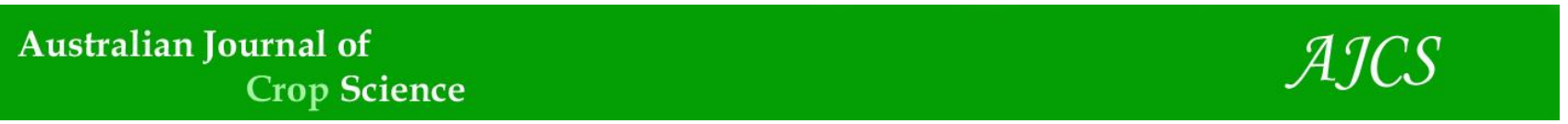

AJCS 14(08):1283-1287 (2020)

ISSN:1835-2707

doi: 10.21475/ajcs.20.14.08.p2435

\title{
Comparison of methods to evaluate resistance of lettuce genotypes against Bremia lactucae
}

\author{
Ana Carolina Pires Jacinto ${ }^{1}$, Aline José da Silveira ${ }^{1}$, Isadora Gonçalves da Silva ${ }^{1}$, Renata Castoldi* ${ }^{1}$, \\ Carolina Andrade Franco ${ }^{3}$, Rafael Resende Finzi ${ }^{1}$, Marcus Vinícius Marin ${ }^{2}$, Leila Trevisan Braz ${ }^{3}$, Gabriel \\ Mascarenhas Maciel ${ }^{1}$
}

\author{
${ }^{1}$ Instituto de Ciências Agrárias, Universidade Federal de Uberlândia, Campus de Monte Carmelo, CEP: 38.500-000, \\ Monte Carmelo, MG, Brasil \\ ${ }^{2}$ Gulf Coast Research and Education Center, University of Florida, Zip Code: 33598, Wimauma, Florida, United States \\ ${ }^{3}$ Departamento de Produção Vegetal, Universidade Estadual Paulista "Júlio de Mesquita Filho", CEP: 14.884-900, \\ Jaboticabal, SP, Brasil
}

Correspondence author: rcastoldi@ufu.br

Abstract

For the lettuce crop, there is no specific or standard methodology to evaluate genotype resistance of lettuce against downy mildew. Therefore, the aim of this work was to compare three methodologies for the identification of resistance to downy mildew. The experiment was carried out at Universidade Federal de Uberlândia, Monte Carmelo Campus between 2017 and 2018 . The statistical method used was a completely randomized design with 12 treatments (cultivar Solaris, used as a control; and 11 genotypes of lettuce F5: 6: UFU-Crespa 75 \# 2, UFU-Crespa 189 \# 2, UFU-Crespa 206 \# 1, UFU-Lisa 66 \# 3, UFU-Lisa 66 \# 7, UFU-Lisa 215 \# 3, UFU-Lisa 215 \# 6, UFU-Lisa 215 \# 10, UFU-Lisa 215 \# 12, UFU-Lisa 215 \# 13, UFU-Lisa 215 \# 14) and four replications. The seeding of genotypes was carried out in transparent boxes and after 15 days the inoculation was performed using a spore suspension $\left(1 \times 10^{4}\right.$ sporangia/ml) and sterile deionized water for the controls. The disease progression was assessed by three methods: Mesquita, Dickinson \& Crute and Horsfall \& Barrat. The data were standardized and submitted to the univariate analysis of variance by the $\mathrm{F}$ test and multivariate analyzes. The univariate clustering results allowed the separation of the genotypes into two distinct resistance groups for the Dickinson \& Crute and Mesquita methods. In the multivariate analysis, more formation of groups among genotypes with different levels of resistance to downy mildew in the Mesquita method was observed. The methodology proposed by Mesquita was more efficient in discriminating genotypes with different levels of resistance to downy mildew, separating them in a larger number of groups.

Keywords: Downy mildew; Lactuca sativa L.; methodologies; multivariate analyzes; plant breeding.

\section{Introduction}

The lettuce downy mildew, caused by the biotrophic oomycete Bremia lactucae, is one of the main diseases of lettuce crop, because it reduces the quality of the leaves the marketable part of the crop - and is often accentuated by post-harvest losses, which occur during transport and storage (Kunjeti et al., 2016; Parra et al., 2016). Symptoms of lettuce downy mildew usually occur as pale-yellow, angular patches delineated by the veins of the leaves. On the abaxial side of the leaves, the presence of white sporangia, consisting of sporangiophores and sporangia is observed (Mieslerová et al., 2013).

The disease management of lettuce downy mildew is mainly done through fungicide application and use of resistant cultivars, carrying Dm genes or resistance factors $\mathrm{R}$, which express hypersensitivity reaction (Castoldi et al., 2014; Tobar-Tosse et al., 2017). However, in the literature there is a lack of standard methodologies for evaluation of resistance, tolerance or susceptibility of genotypes against $B$. lactucae.
There are four basic measures that can be used for quantification of diseases: incidence, severity, intensity and density of the pathogen. However, several studies (Petrželová et al., 2011; Araújo et al., 2014; Castoldi et al., 2014; Tobar-Tosse et al., 2017) use only the percentage of sporulated plants considering: highly resistant cultivars, those with sporulated plant numbers less than or equal to five percent, and cultivars with incomplete resistance, those with sporulated plant numbers between five and twenty percent. However, such methodology may not be the most adequate, or even be prone to subjectivity, and might generate inconsistent results.

The methodology described by Horsfall \& Barrat (1945) was selected by Teramoto et al. (2011) to evaluate the resistance of cucumber hybrids to the fungus Corynespora cassiicola. However, Jemelková et al. (2015) used the Dickinson \& Crute (1974) scale to examine the variation in downy mildew ( $B$. lactucae) resistance of Lactuca aculeata genotypes from different geographical origins. However, Tobar-Tosse et al. 
(2017) evaluated the resistance of curly lettuce strains to downy mildew breeds, based on the scale proposed by Mesquita (2008).

Taking into account that the lettuce breeding programs are focused on the selection of materials that combine resistance or tolerance to pests and diseases and high productivity, the disease evaluation should use methods that allows quick and reliable results. Therefore, this study aimed compare three methodologies for identifying resistance to diseases, in order to define the more suitable for evaluation of lettuce genotypes against downy mildew.

\section{Results}

In general, lettuce genotypes presented distinct behaviors for resistance to $B$. lactucae. The identification of genotypes with more or less resistance varied according to the analysis used (multivariate or univariate analyzes).

Results of univariate clustering by the Scott-Knott test $(p=$ 0.05 ) allowed the separation of the genotypes into two distinct groups for reaction to $B$. lactucae for the Dickinson $\&$ Crute and Mesquita methods (Table 1). According to the means of such methods it is possible to separate some genotypes from the susceptible cultivar Solaris and identify genotypes resistant to $B$. lactucae race 1 . However, it was not observed when using the methodology of Horsfall \& Barrat, in which there was no distinguishing between genotypes in groups, pointing out that all evaluated genotypes present the same reaction to $B$. lactucae, and therefore, all susceptible to mildew.

According to the Mesquita method, five genotypes were resistant, showing no signs of the pathogen in the leaves after inoculation (zero score), whereas by the methodology of Dickinson \& Crute, eight genotypes were resistant to downy mildew. However, they formed only two groups resistant and susceptible. Therefore, in addition to univariate analyzes, it is important to use multivariate analyzes to distinguish genotypes with moderate resistance to downy mildew.

Figure 1 represents the graphical dispersion in the twodimensional space of the 12 genotypes under study, using the first and second canonical variables. The two canonical variables explained $85.53 \%, 91.48 \%$ and $96.33 \%$ of the total variation, respectively for Dickinson \& Crute methodologies (Figure 1A), Horsfall \& Barrat (Figure 1B) and Mesquita (Figure 1C).

In the Dickinson \& Crute methodology it was possible to separate the genotypes into three groups, group I(susceptible to mildew): cultivar Solaris; group II(resistant to mildew): UFU-Crespa 189 \# 2, UFU-Crespa 206 \# 1 and UFULisa 215 \# 12 genotypes; and group III (tolerant to mildew): genotypes UFU-Crespa 75 \# 2, UFU-Lisa 66 \# 3, UFU-Lisa 66 \# 7, UFU-Lisa 215 \# 3, UFU-Lisa 215 \# 6, UFU-Lisa 215 \# 10, UFU-Lisa 215 \# 13 and UFU-Lisa 215 \# 14. By the methodology of Horsfall \& Barrat, the genotypes were separated into only two groups, group I(susceptible to mildew): cultivar Solaris; and group II(resistant to mildew): all other genotypes. Already by the methodology of Mesquita, there were the separation of the genotypes in four groups, being group I (susceptible to mildew): cultivar Solaris; group II(resistant to mildew): UFU-Crespa 189 \# 2, UFU-Crespa 206 \# 1 and UFU-Lisa 215 \# 12 genotypes; group III(moderately resistant to mildew): UFU-Crespa 75 \# 2, UFULisa 215 \# 6 and UFU-Lisa 215 \# 13 genotypes; and group IV(tolerant to mildew): genotypes UFU-Lisa 66 \# 3, UFU-Lisa
66 \# 7, UFU-Lisa 215 \# 3, UFU-Lisa 215 \# 10 and UFU-Lisa 215 \# 14.

\section{Discussion}

Cruz and Carneiro (2006) point out that the analysis by canonical variables should only be used when, in two or three canonical variables, more than $80 \%$ of the total variation is explained. Therefore, it can be affirmed that there was a satisfactory description of the genetic divergence represented graphically. It is important to point out that when genetic diversity is studied by canonical variables, the purpose is to identify similar genotypes in bi or three-dimensional scatterplots (Stähelin et al., 2011).

The groups formed by means of the graphic dispersion follow a distinct tendency of the groupings formed through the means test, for all the methodologies studied. This disagreement between multivariate and univariate methods was also observed by other authors, working with different species, such as Nunes et al. (2011a, b), and Azevedo et al. (2013). Regardless of the methodology used, it can be seen that the graphic dispersion of the canonical variables clearly demonstrated the high genetic dissimilarity between the commercial cultivar Solaris and the lettuce genotypes $F_{5: 6}$, in which the cultivar Solaris is susceptible to race 1 of Bremia lactucae and the evaluated genotypes have different degrees of resistance. These results corroborate with the work of Castoldi et al. (2012), who state that the cultivar Solaris is susceptible to all breeds of $B$. lactucae identified so far. Through the multivariate analysis, it was verified that the method proposed by Mesquita (scale of notes) was more efficient in discriminating the genotypes, separating them in a larger number of groups. The same occurred with the Scott Knott test, in which the methods of Mesquita and Dickinson and Crute allocated the genotypes in distinct groups. The notes scale of the Mesquita method refers to the observation of the presence or absence of mildew on the leaves, so that the note is attributed considering the day the symptom was identified. This is a simple measurement method, in which the severity of the disease is not considered, being a less subjective and error-prone evaluation. There is no scale of notes or a specific method for the analysis of lettuce mildew. In the present study, a number of authors (Petrželová et al., 2011; Araújo et al., 2014, and Tobar-Tosse et al., 2017) only the percentage of sporulated plants, which are: highly resistant cultivars which present sporulated plant numbers less than or equal to five percent; and cultivars with incomplete resistance - those that present sporulated plant numbers between five and twenty percent. The results of this study reinforce the need to standardize a methodology for evaluation of lettuce mildew, suggesting the Mesquita method as the most efficient to discriminate lettuce genotypes with different levels of resistance to downy mildew, between the compared methods in this study.

Materials and methods

\section{Experiment location and plant material}

The experiment was conducted at the LAGEN (Laboratory of Seed Analysis and Genetic Resources) located at the Universidade Federal de Uberlândia, Monte Carmelo campus between 2017 and 2018. 
Table 1. Reaction of lettuce genotypes to Bremia lactucae, based on the Dickinson \& Crute methods (area below the disease progress curve); Horsfall \& Barrat (disease severity); and Mesquita (scale of notes).

\begin{tabular}{llll}
\hline Groups $^{1}$ & \multicolumn{3}{l}{ Number of genotypes and severity $(\%)^{2}$} \\
\cline { 2 - 4 } I & Dickinson \& Crute & Horsfall \& Barrat & Mesquita \\
II & $8(4.65 \pm 7.25) \mathrm{a}$ & $12(1.64 \pm 1.05)$ & $5(0.00 \pm 0.00) \mathrm{a}$ \\
& $4(44.32 \pm 16.00) \mathrm{b}$ & - & $7(88.75 \pm 11.55) \mathrm{b}$ \\
\hline
\end{tabular}

${ }^{1}$ Means followed by distinct letters in the column differ from each other by the Scott-Knott test at 0.01 and 0.05 significance. ${ }^{2}$ Enter parentheses, means of the genotypes in each grouping.

A
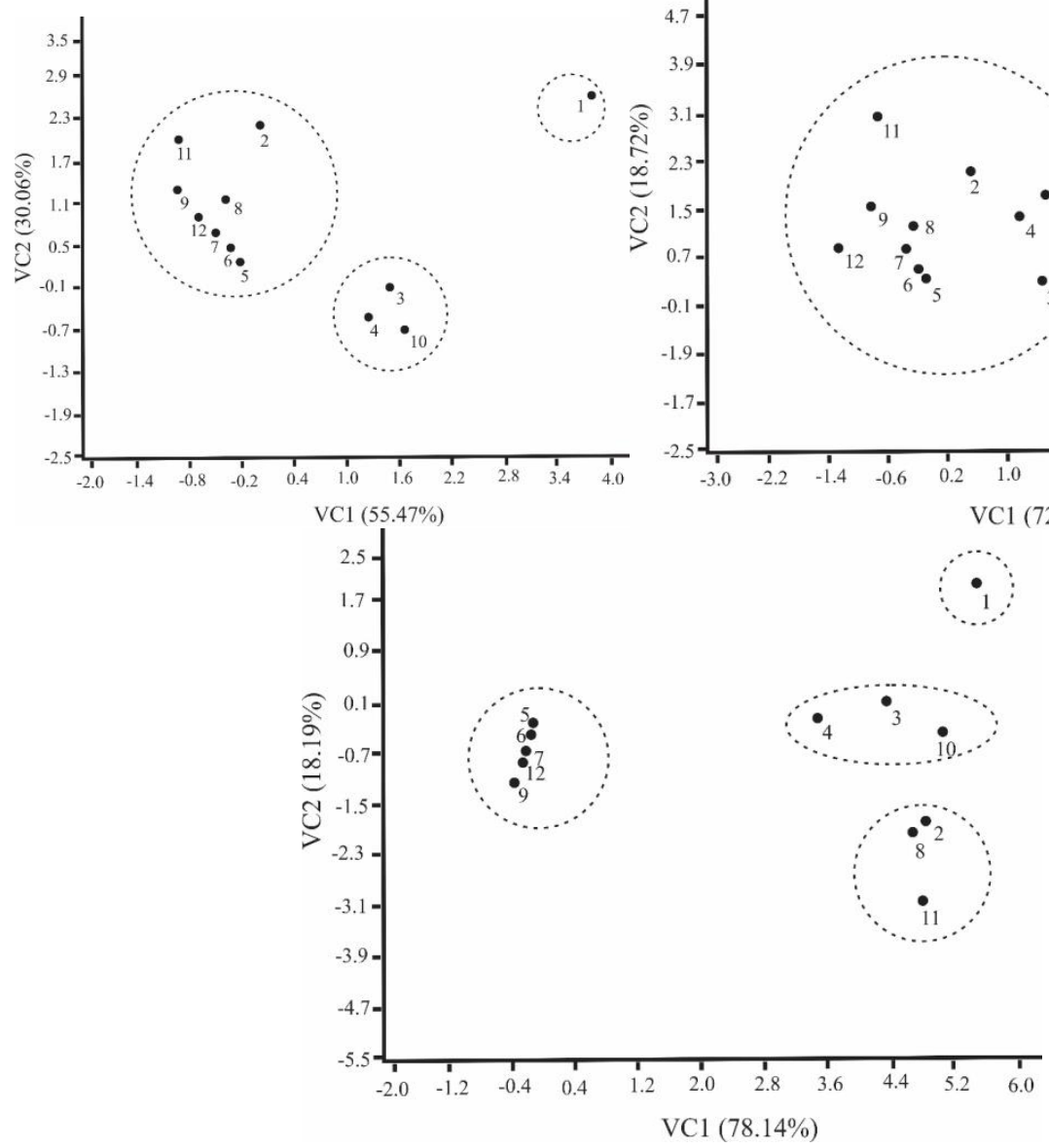

Fig 1. Graphical dispersion of the scores in relation to the two representative axes of the first two Canonic Variables (VC1 and VC2), by Dickinson \& Crute (A), Horsfall \& Barrat (B) and Mesquita (C) methods. Numerals indicate lettuce genotypes, where $1=$ Solaris; 2 = UFU-Lisa 66 \# 3; 3 = UFU-Lisa 66 \# 7; 4 = UFU-Crespa 75 \# 2; 5 = UFU-Crespa 189 \# 2; 6 = UFU-Crespa 206 \# 1; 7 = UFU-Lisa 215 \# 3; 8 = UFU-Lisa 215 \# 6; 9 = UFU-Lisa 215 \# 10; 10 = UFU-Lisa 215 \# 12; 11 = UFU-Lisa 215 \# 13; 12 = UFU-Lisa 215 \# 14.

To compare the different methodologies for evaluation of genotype resistance, the commercial cultivar Solaris was used as a control, being susceptible to all $B$. lactucae strains (Castoldi et al., 2012) and 11 genotypes of lettuce F5: 6 (UFU-Crespa 75 \# 2, UFU-Crespa 189 \# 2, UFU-Crespa 206 \# 1, UFU-Lisa 66 \# 3, UFU-Lisa 66 \# 7, UFU-Lisa 215 \# 3, UFULisa 215 \# 6, UFU-Lisa 215 \# 10, UFU-Lisa 215 \# 12, UFU-Lisa 215 \# 13, UFU-Lisa 215 \# 14). The F5:6 genotypes used came from the cross between the cultivar Uberlândia 10,000 (Sousa et al., 2007) $x$ cv. Pira $63\left(\right.$ Tecnoseed $^{\circledR}$ ) belonging to the Program for Genetic Improvement of Biofortified Lettuce of UFU.

\section{Inoculum production and inoculation of B. lactucae}

The multiplication of the $B$. lactucae race 1 was carried out in the susceptible cultivar Solaris until sufficient amount of inoculum was obtained for the inoculations. After multiplication, 30 seeds of each genotype previously disinfested (using 70\% alcohol and 1:1 water + hypochlorite) were seeded in plastic boxes $(11 \times 11 \times 3.5 \mathrm{~cm})$, lined with two substrate sheets of paper moistened and maintained for 15 days in incubation chamber type BOD (Biochemical Oxygen Demand) at $13^{\circ} \mathrm{C}$ temperature and photoperiod of $12 \mathrm{~h}$, to favor emergence of seedlings and expansion of cotyledonary leaves. When the seedlings presented two cotyledonary leaves completely expanded, the inoculation with the isolate of $B$. lactucae race 1 was carried out, according to the technique of llott et al. (1987), using suspension of sporangia removed from infected tissues of the host in distilled water containing surfactant (Tween 20), in order to increase the sporangia adhesion in cotyledonary leaves Marin et al. 2019. The spore suspension was calibrated to $10^{\wedge} 4$ sporangia/ $\mathrm{ml}$ and a Pasteur-type pipette was used for each isolate for inoculation until runoff. After inoculation, the boxes were placed in a BOD incubation chamber with a temperature of $13^{\circ} \mathrm{C}$, and for the first six hours they were kept in a darkroom and after that time the photoperiod was adjusted to 12 hours. 


\section{Experimental design and comparison of methods}

The statistical design was completely randomized, with 12 treatments (commercial cultivar susceptible to mildew +11 biofortified lettuce genotypes F5:6) and four replications. The progress of the disease was evaluated by means of three patometric methods described below:

a) Methodology proposed by Mesquita (2008), with modifications, so thatthe seedlings that showed the first signs of B. lactucae, received higher grades, as described: 12 $=$ plants that showed signs of the pathogen on the $7^{\wedge}$ th day after inoculation; 11 = plants showing signs of the pathogen on the $8^{\wedge}$ th day after inoculation; $10=$ plants showing signs of the pathogen on the $9^{\wedge}$ th day after inoculation; $9=$ plants showing signs of the pathogen on the $10^{\wedge}$ th day after inoculation; 8 = plants showing signs of the pathogen on the $11^{\wedge}$ th day after inoculation; $7=$ plants showing signs of the pathogen on the $12^{\wedge}$ th day after inoculation; $6=$ plants showing signs of the pathogen on the $13^{\wedge}$ th day after inoculation; 5 = plants showing signs of the pathogen on the $14^{\wedge}$ th day after inoculation; 4 = plants showing signs of the pathogen on the $15^{\wedge}$ th day after inoculation; $3=$ plants showing signs of the pathogen on the $16^{\wedge}$ th day after inoculation; 2 = plants showing signs of the pathogen on the $17^{\wedge}$ th day after inoculation; 1 = plants showing signs of the pathogen on the $18^{\wedge}$ th day after inoculation; $0=$ plants that did not show signs of the pathogen after inoculation.

b) Methodology described by Dickinson \& Crute (1974), where: 0 = absence of sporangiophores visible on leaves; 1 = limited sporulation, sporadic sporangiophores present; 2 = less than $50 \%$ of the cotyledons covered with sporangiophores and $3=$ more than $50 \%$ of the cotyledons covered with sporangiophores. The plants were evaluated over $18^{\wedge}$ th days, and the intensity of the disease was then calculated, which was expressed as percentage, according to the following formula: ID (\%): $\Sigma\left[\left(\left(^{*} v\right) /\left(n^{*} x\right) 100\right]\right.$. From the disease intensity data, the area under the disease progress curve (AUDPC) was calculated using the formula AUDPC $=\Sigma[(\mathrm{y} 1+\mathrm{y} 2) / 2) *(\mathrm{t} 2-\mathrm{t} 1)]$, where $\mathrm{y} 1$ and $\mathrm{y} 2$ are two consecutive evaluations performed at times $t 1$ and $t 2$, respectively (Campbell e Madden, 1990).

c) Methodology proposed by Horsfall \& Barrat (1945), based on classes, according to the severity percentage of the disease, where: class $0=0 \%$; class $1=$ greater than 0 up to $3 \%$; class 2 = greater than 3 to $6 \%$; class $3=$ greater than 6 to $12 \%$; class $4=$ greater than 12 to $25 \%$; class $5=$ greater than 25 to $50 \%$; class $6=$ greater than 50 to $75 \%$; class $7=$ greater than 75 to $87 \%$; class $8=$ greater than 87 to $94 \%$; class $9=$ greater than 94 to $97 \%$; class $10=$ greater than 97 to less than $100 \%$; class $11=100 \%$.

On the 18th day after inoculation, when all the evaluations were finished by means of the three patometric methods, the percentage of necrotic and sporulated seedlings was also evaluated. The evaluation of the percentage of necrosis and sporulated plants was carried out only with the purpose of performing the multivariate analysis, since their values were fixed among the methods. In the determination of dissimilarity, only the established criteria of each method were varied: area below the disease progression curve (Dickinson e Crute, 1974), disease severity (Horsfall e Barrat, 1945) or grading scale (Mesquita, 2008).

\section{Statistical analysis}

The data were standardized and then submitted to univariate analysis of variance by the $F$ test $(p=0.05)$. In the standardization, the values obtained in each of the different note scales were divided by the highest note of the respective scaled scale and then multiplied by 100 . Subsequently, the means were grouped and compared by the Scott-Knott test $(p=0.05)$.

In addition, multivariate analyzes were carried out to determine the dissimilarity between the genotypes, obtaining the matrix of dissimilarity by the generalized distance of Mahalanobis ("D"). Multivariate analysis was performed for each method and, also, correlation analysis among its matrices of dissimilarity. The groupings were visualized through a Cartesian graph by the analysis of Canonic Variables (Cruz et al., 2012). All the data obtained were analyzed using the software Genes (Cruz, 2013).

\section{Conclusions}

The methodology proposed by Mesquita is more efficient in discriminating genotypes with different levels of resistance to downy mildew, because it allows grouping the genotypes into five classes: susceptible; tolerant moderately resistant and resistant to mildew.

\section{Acknowledgments}

Universidade Federal de Uberlândia, for allow the use of its facilities; Universidade Estadual Paulista "Júlio de Mesquita Filho", Campus de Jaboticabal, for sending the Bremia lactucae isolates; Conselho Nacional de Desenvolvimento Científico e Tecnológico (CNPq), for the scholarsip to the first author.

\section{References}

Araújo JC, Gomez LAG, Fiorini ACV, Dutra TODO (2014) Reação de resistência ao míldio e seleção de genótipos nacionais resistentes em população F2 de alface americana. Rev Agrogeoambiental. 6:11-19.

Azevedo AM, Andrade Júnior VC, Oliveira CM, Fernandes JSC, Pedrosa CE, Dornas MFS, Castro BMC (2013). Seleção de genótipos de alface para cultivo protegido: divergência genética e importância de caracteres. Hortic Bras. 31:260265.

Campbell CL, Madden LV (1990) Introduction to plant disease epidemiology. John Wiley Professio, New York.

Castoldi R, Charlo HCO, Dalpian T, Melo DM, Botelho AP, Braz LT (2012) Identification of new Bremia lactucae races in lettuce in São Paulo state. Hortic Bras. 30:209-213.

Castoldi R, Charlo HCO, Melo DM, Candido WS, Vargas PF, Dalpian T, Braz LT (2014) Obtaining resistant lettuce progenies to downy mildew. Hortic Bras. 32:69-73.

Cruz CD (2013) Genes: a software package for analysis in experimental statistics and quantitative genetics. Acta SciAgron. 35:271-276.

Cruz CD, Regazzi AJ, Carneiro PCS (2012) Modelos biométricos aplicados ao melhoramento genético. 4th Ed. UFV, Viçosa, Brasil.

Cruz CD, Carneiro, PCS (2006) Modelos biométricos aplicados ao melhoramento genético. 2. Ed. UFV, Viçosa, Brasil, 2v. 
Dickinson CH, Crute IR (1974) The influence of seedling age and development on the infection of lettuce by Bremia lactucae. Ann Appl Biol. 76:49-61.

Horsfall JG, Barrat RW (1945) An improved grading system for measuring plant diseases. Phytopathology. 35:665.

Ilott TW, Durgan ME, Michelmore RW (1987) Genetics of virulence in California populations of Bremia lactucae (Lettuce Downy Mildew). Phytopathology. 77:1381-1386.

Jemelková $M$, Kitner $M$, Křístková $E$, Beharav $A$, Lebeda $A$ (2015) Biodiversity of Lactuca aculeata germplasm assessed by SSR and AFLP markers, and resistance variation to Bremia lactucae. Biochem Syst Ecol. 61:344356.

Kunjeti SG, Anchieta A, Martin FN, Choi YJ, Thines M, Michelmore RW, Koike ST, Tsuchida C, Mahaffee W, Subbarao KV, Klosterman SJ (2016) Detection and quantification of Bremia lactucae by spore trapping and quantitative PCR. Phytopathology. 106:1426-1437.

Marin MV, Franco CA, Smilde D, Panizzi RC, Braz LT (2020) Distribution of races and virulence factors of Bremia lactucae in the main lettuce production area in Brazil. J. Plant Pathol. 102:395-407.

https://doi.org/10.1007/s42161-019-00444-x

Mesquita PG (2008) Biologia, epidemiologia e controle do míldio (Bremia lactucae) da alface (Lactuca sativa) em viveiro. Dissertation, Universidade de Brasília. Brasília, DF, Brasil.

Mieslerová B, Lebeda A, Petrzelova I, Korbelova P (2013) Incicence of lettuce downy mildew (Bremia lactucae) and powdery mildew (Golovinomyces cichoracearum) in natural populations of prickly lettuce (Lactuca serriola). Plant Protect Sci. 49:24-32.

Nunes GH, Costa Filho JA, Silva DJH, Carneiro PCS, Dantas DJ (2011a) Divergência genética entre linhagens de melão pele de Sapo. Rev Cienc Agron. 42: 765-773.

Nunes GH, Melo DRM, Dantas DJ, Aragão FAZ, Nunes EWL (2011b) Divergência genética entre linhagens de melão do grupo Inodorus. Rev Cienc Agron. 42: 448-456.

Parra L, Maisonneuve B, Lebeda A, Schut J, Christopoulou M, Jeuken M, Mchale L, Truco MJ, Michelmore R (2016) Rationalization of genes for resistance to Bremia lactucae in lettuce. Euphytica. 210:309-326.

Petrželová I, Lebeda A, Beharav A (2011) Resistance to Bremia lactucae in natural populations of Lactuca saligna from some Middle Eastern countries and France. Ann Appl Biol. 159:442-455.

Sousa CS, Bonetti AM, Goulart Filho LR, Machado JRA, Londe LN, Baffi MA, Ramos RG, Vieira CU, Kerr WE (2007) Divergência genética entre genótipos de alface por meio de marcadores AFLP. Bragantia. 66:11-16.

Stähelin D, Oliveira FJ, Anunciação Filho CJ, Neto DES, Melo LJOT (2011) Screening multivariado entre acessos e cultivares de feijão do grupo preto para utilização em blocos de cruzamento. Rev Biotemas. 24:35-103.

Teramoto A, Martins MC, Ferreira LC, Cunha MG (2011) Reaction of hybrids, inhibition in vitro and target spot control in cucumber. Hortic Bras. 29: 342-348.

Tobar-Tosse DE, Candido WS, Marin MV, Panizi RC, Barbosa JC, Braz LT (2017) Resistance of green leaf lettuce lines to the Bremia lactucae races identified in São Paulo state. Summa Phytopathologica. 43:55-57. 